\title{
Strategic Partnership and Equity Alliances in the Function of Crisis Prevention and Elimination
}

\author{
Drago Dubrovski \\ International School for Social and Business Studies, Celje, Slovenia \\ Email:drago.dubrovski@mfdps.si
}

How to cite this paper: Dubrovski, D. (2016) Strategic Partnership and Equity Alliances in the Function of Crisis Prevention and Elimination. Modern Economy, 7, 1385-1395.

http://dx.doi.org/10.4236/me.2016.712128

Received: September 7, 2016

Accepted: October 28, 2016

Published: November 1, 2016

Copyright $\odot 2016$ by author and Scientific Research Publishing Inc. This work is licensed under the Creative Commons Attribution International License (CC BY 4.0).

http://creativecommons.org/licenses/by/4.0/

\begin{abstract}
Crisis management comprises planning, organizing, directing and monitoring companies experiencing difficulties that directly endanger their existence and further development and its purpose is to stop negative trends by achieving a drastic change and providing the foundation for redevelopment. The short-term measures of crisis management that put an end to negative movements (survival) in the first phase, must be followed in the second phase by middle- or long-term measures of ensuring development that are mostly connected to revolutionary changes. In regard to a corporation's situation from its endangerment or the prospects point of view, restructuring as a method of revolutionary changes can have the different roles in crisis solving, crisis prevention, accelerated development of a corporation, insolvency procedures and business and equity alliances. For many companies or even industries, the inclusion into a strategic partnership at a certain level of development is not only a strategic possibility and opportunity, but also a business necessity, as this is the only way to preserve a competitive market position and prevent the occurrence of acute crisis in the future. On the other hand, it is also possible to heal a company crisis with strategic connections and equity alliances; whereby available assets and partner companies' capabilities are also included into the healing process, which is also in search of synergy effects. Based on the theoretical discussion and empirical findings from the author's research, two statements that were set forth in advance were confirmed. Strategic partnerships and equity alliances are often in the function of crisis prevention and management and they are inseparably connected with revolutionary changes, as positive effects cannot be achieved otherwise.
\end{abstract}

\section{Keywords}

Crisis, Crisis Management, Restructuring, Strategic Partnership, Equity Alliance 


\section{Introduction}

A crisis is a short-term undesired, unfavourable and critical situation in a company (organization), directly endangering the existence and further development of this organization and is caused by an intertwined and simultaneous action of both external and internal sources ([1] [2]; cf. also [3]-[5]).

In terms of the management of the company or strategic business decision makers, crisis brings exceptional situations, which require very rapid decision-making due to the critical state of the moment, and these decisions must be as correct as possible; as usually adjustments are not possible, therefore the crisis also contains a managerial viewpoint. Emergency situations represent a situation in which it is not possible to use tried and tested routine decisions, as the company is facing these new situations (at least in this way) for the first time. The timing and decision-making pressure is in contrast with the causes and the course of the emergence of the crisis, which is usually a long-term process. The management of the company is therefore directly confronted with the characteristics of emergency situations that require a different approach by the company's management, as opposed to normal conditions.

Crisis management comprises planning, organizing, directing and monitoring companies (organizations) experiencing difficulties that directly endanger their existence and further development and its purpose is to stop negative trends by achieving a drastic change and providing the foundation for redevelopment.

It is necessary to point out that the crisis management has two fundamental tasks: stopping negative trends (short-term operation) and defining new foundations for further development (middle-term operation). Managing a crisis situation (condition) alone ensures the company its survival, but not the recovery of the company (temporary standstill of the crisis). Therefore, this phase must be followed by the earliest possible achievement of a drastic change (or turnaround), when negative trends, after hitting rock bottom (turning point), turn towards positivity, where the company ensures its existence and the realization of a development option or along with the temporary existence also further competitive development. The management of a crisis situation itself does not serve any purpose, since a crisis situation is considered de facto managed only when the turnaround of a negative direction trend towards a positive direction is achieved.

The short-term measures of crisis management that put an end to negative movements (survival) in the first phase, must be followed in the second phase by middle- or long-term measures of ensuring development that are mostly connected to revolutionary changes.

There are many researches focused on the applicable measures in crisis management or revolutionary changes on one side and strategic alliances on another side; however, only limited reports can be found treating these two concepts interlinked. In our research, therefore, we put forward several hypotheses; however, the object of this contribution includes the following hypotheses:

- H1: Even the largest production companies ensure both their continuous existence 
and development with strategic partnership and equity alliances; the latter play a particularly important role when it comes to crisis prevention and elimination.

- H2: When strategic partnerships and equity alliances act in the function of crisis prevention and elimination, an inseparable connection with the methods of revolutionary changing exists (restructuring, reengineering).

\section{Entering into Strategic Partnerships in Order to Achieve the Necessary Revolutionary Changes}

Causes (reasons) for the formation of many strategic partnerships in the form of strategic business relationships and capital ties lie in the increasingly intensified international competition, technological and general progress and the effects of globalization. Therefore, the purpose of strategic partnerships is maintaining and increasing the common (global) competitive edge that enables further existence and boosts the development of affiliated companies in the harsh economic conditions. However, on the basis of the connected, combined and adjusted in-depth cooperation, the overall objective (basic motive) is achieving synergy, i.e. an additional effect that each individual company would not be able to achieve on their own. The actual objectives (motives) for each individual relationship and each participant may differ.

Various authors (e.g. [6]-[15]) determine objectives quite differently in terms of terminology, although in terms of substantive viewpoint we can speak of more or less similar objectives. Some authors such as Berstein [16] and Brouthers, van Hastenburg \& van den Ven [17] try to define objectives which pertain only to capital mergers. The goals for establishing relationships may be strategic for strategic partnerships; operative in the case of the realization of common tactical and implementation operations; and internal in the case of managing only internal relationships. On the one hand, the actual objectives of in-depth and more complex strategic cooperation usually pertain to solving development issues and, on the other hand, the utilization of opportunities which means that it is either a case of efforts to eliminate the deficit in available assets or optimal as well as a complementary synergetic utilization of available assets and capabilities of the participants in the relationship which, when acting as individual companies, fail to manage all the key operative areas or the return value is too low due to various reasons.

The final purpose of establishing relationships is the continued existence and accelerated development of the affiliated companies since the internal (organic) growth may be (too) slow and uncertain. Development can take place in the context of company activities, within the same industry or outside the industry. Therefore, the concept of growth can be based on an independent path where resources, growth through business relationships and capital ties (adding new capabilities, programmes, resources, etc.) and growth by integrating and diversification (takeovers of suppliers, client and delivery channel activities) are often limited. Acquisition of development potentials through a strategic business partnership and capital takeovers, as well as mergers by acquisition can therefore represent a quicker and often cheaper and less complex development path 
than developing own capabilities (organic growth), while speed is nowadays often of crucial importance for success in the increasingly competitive environment. Strategic partnerships therefore enable the achievement of certain advantages that cannot be obtained in any other way.

After they have formed a capital tie, the participating companies must often completely renew their operations and once again achieve compliance between the strategy and structure, strategy and management, strategy and corporate culture as well as the strategy and interests of influential participants. Renewal of a company brings about new processes, systems, strategies, programmes and structures which ensure the company to achieve a higher level of development on the basis of improved effectiveness and operational performance. The process of the business integration of the affiliated companies which will lead to a renewal of the new (merged, partner-affiliated) company can mostly be performed only through methods of revolutionary changes which also include the method of restructuring (reforming structures) and the method of reengineering (process restructuring). Restructuring and reengineering are therefore methods of revolutionary changes and also methods of achieving the reorganization of a company which are normally necessary in crisis prevention or management.

\section{Content and Manifestations of a Strategic Partnership}

In business practice, there is an extreme diversity of forms of business cooperation between companies that are the result of the characteristics and particularities of each business system, the environment in which it operates, as well as the characteristics and particularities of the very connection of the two already particular business systems. As to whether a company will ensure its continuous existence independently, merely by improving all internal basic capabilities and assets or through merging, and combining these with other companies, is a key strategic question, often one of the most important ones in the entire period of a company's operations.

For many companies or even industries, the inclusion into a strategic partnership at a certain level of development is not only a strategic possibility and opportunity, but also a business necessity, as this is the only way to preserve a competitive market position and prevent the occurrence of acute crisis in the future. On the other hand, it is also possible to heal a company crisis with strategic connections and equity alliances, whereby available assets and partner companies' capabilities are also included into the healing process, which is also in search of synergy effects.

A partnership is an adapted business relationship that is based on mutual trust, openness, joint risk and common benefits that increase the competitive advantage with better business efficiency that the companies would achieve on their own. A partnership is known for its deepened cooperative behaviour that requires a reciprocal adjustment of means and the behaviour of partners.

Hence, such an instance does not only revolve around the same course of interests (alliance), but also the mutual adjustment and harmonization between the connected companies-each partnership participant must renounce something in order to gain 
something else. The contact surface between companies that are connected in such a way is significantly greater and, therefore, more solid than in than in the case of alliances as the sum of the potential of the two companies.

The content characteristics of a strategic partnership that differentiate such a relationship from a classic rivalry or purchase relationship are [18]:

- reciprocal adjustment of assets and participants' behaviour instead of the mere accumulation that is typical for an alliance,

- inclusion of a development component: partnership companies are participating in the joint, combined or complementary development of all programs and activities or of only some parts and projects, whereby the developmental cooperation increases their co-dependence and the intensity of participants in such a relationship,

- long-term cooperation: as this is a reciprocal challenging adjustment of systems, processes, structures and strategies of the participants and also include a joint development component as the partnership relationship can only be a long-term one,

- the distribution of risks and results: in a partnership relationship, all participants, on the one hand, share the risks of the partnership cooperation that are related to various investments and adjustments, and, at the same time, also share results, either positive or negative, naturally in the part that applies to the partnership cooperation on the other hand.

Hence, when establishing connections, the accumulation of assets (potentials, resources) occurs first, then comes their analysis and a business evaluation from the perspective of the set long-term goals and strategies that are followed by their allocation and, in the end, the acceleration of some and the cancellation (sale) of others. Companies that are connected this way change their programs, systems, structures and processes based on the methods of radical changes (restructuring, reengineering). Due to these often wide-ranging renovation processes, a long-term relationship is typical of a strategic partnership as partners cannot harmonize with each other and adjust overnight if they wish to achieve synergy effects. A strategic partnership is a formalized long-term relationship with other companies with whom a goal can be reached by compensating weaknesses with stronger potentials of other organizations with which the competitive position of a certain company or group of companies is secured and improved in the long-term (Sydow in [19]).

A manifestation of a strategic partnership can be:

- a business (non-equity, non-ownership) association or alliance,

- or an equity (ownership) alliance.

Naturally, it should be immediately pointed out that both manifestations may overlap, as capital alliances are often aimed at the realization of business goals and have the characteristics of a business partnership. However, it is also true that every ownership connection is neither of a strategic nor business or partnership nature. Hence, the case at hand requires that we first determine whether this relationship has the characteristics of a strategic partnership (reciprocity, development component, long-term nature, distribution of risks and results), as only then can we make conclusions on the manifesta- 
tions of such partnership relationships.

Equity alliances are a manifestation of a strategic partnership in which equity, ownership, status and statutory changes occur in relation to all participating companies. Capital as a source of financing company assets are invested into the company by the owners in order to pursue joint interests in the determined area. The composition of equity shares also includes ownership composition, whereas the size of these shares dictate the scope of managerial rights of an individual owner. If individual owners sell their equity shares (transfer, alienate), then the ownership and equity structure changes accordingly. Through capital mergers and joint investments, the transformation of connected companies occurs in such a way that the legal (and business) status changes as well as the status of participating companies, new basic rules need to be formed, i.e. the articles of association of the newly-created legal form of the participating companies. Hence, equity alliances cause a material (transfer) status transformation of the participating companies, for which it is typical that they are connected with the transfer of all assets or part thereof to another company. In relation to types of equity alliances, there can be mergers (acquisition and merger of equals), takeovers and joint investments.

Strategic business alliances (business alliances, non-equity agreements) are not based on equity, ownership (derived from "owners") or ownership (derived from "ownership") transactions, as participating companies preserve their legal (status) independence. However, equity alliances revolve around altered ownership relationships which is why, ordinarily, business cooperation should be more intense in this case and the relationship of a more long-term nature; however, it is not necessary for equity alliances to have content elements of strategic business cooperation.

\section{Business Partnerships and Equity Alliances in the Function of Crisis Prevention and Elimination}

The purpose of strategic connections today that were not created due to serious difficulties in one or even both partnership companies is the increase of joint (global) competitiveness which actually means the prevention of the occurrence of a crisis. A company that is developing relatively successfully will, at a certain level, nonetheless, start to fall behind its competitors that have merged their powers and achieved synergy effects that the "independent" company cannot. However, when a strategic business or equity connection is created in cases when one company is in a crisis (the "ugly duckling"), such a connection may bring such a company salvation from crisis. As such a case means the connection of an economically more powerful company with a weaker one, the latter cannot expect to have an equal position in connection processes, which actually represents a sacrifice, as is otherwise typical of all cases of crisis management.

Strategic business partnerships and capital transformations are therefore, important both in the period of prevention of crisis occurrence as well as in the period of crisis management. According to some research [20], in 40\% - 50\% of cases, the key ingredient of the reversal concept is a capital merger and takeover. The purpose of a compa- 
ny undergoing difficulties in such cases is also renovation and recapitalization, which brings the lowering of the burden of debts into the cash flow so that it will comply with the possibilities of acquiring debt, or asset restructuring due to which their liquidity is to improve.

The reason as to why a stronger party would connect with one in an acute crisis ("ugly duckling"), facing the serious threat of a chain reaction that a crisis presents, can lie in the fact that the company in crisis has:

- a market-verified production sales or service program that it cannot properly develop and market due to the lack of all other necessary potential (financial, personnel, technological etc.);

- suitable technology that it cannot exploit optimally as it has problems in the salesmarketing area;

- excellent team of experts that cannot demonstrate their knowledge and capabilities as the company has unsurmountable financial or other problems;

- such fixed and current assets (e.g. investments) with which the partner can achieve a significantly larger utilisation rate and yield;

- a branched distribution network at home or abroad that it cannot maintain due to financial difficulties.

In relation to this, acquisitions and takeovers are divided in two groups; one that represents opportunities (opportunity driven) and those that are directed at solving problems (problem driven) in target companies [13].

In order for a company to avoid the pitfalls that arise from the connection with a company in crisis successfully, in practice, first, pre-connection measures occur that relate to the introduction, if necessary, of very radical activities of healing in the crisis company (out-of-court settlements or compulsory settlements, divestiture, balance "cleanses", even programmed-controlled bankruptcies etc.), or less risky methods (e.g. takeover with the purchase of fixed assets). Naturally, such a situation calls for the precise due diligence of the company that is undergoing difficulties and is the target of the takeover.

In accordance with the changes in the company's environment, they continuously adjust their organization structure to the newly-created circumstances in which they can still maintain or increase the value for shareholders so that they can (often very radically) change the compositions of assets, liabilities, capital and activity.

Divestitures and capital mergers are often tandem-like strategies, especially when they involve the transformation of a portfolio. A divestiture is often the first resource for financing capital takeovers, whereas the acquirer then often sells off some parts of the company that was taken over, which have no strategic value in its further development.

In the period 1970-2006, divestitures were present in $40 \%$ of all capital mergers and takeovers [21].

The consequence of various connections is the international concentration within the industry and service sectors (consolidation of a fragmented sector, [22]), which means 
that there are, when speaking in numbers, fewer and fewer players in individual sectors that are greater in their connections, while various smaller contractors cooperate with this connection (or in this connection) in one way or another (subcontractors, franchisees etc.).

Companies that are buyers of other company's culled activities, often enter other business areas in this way or employ the diversification strategy. Whether the diversification costs outweigh its benefits is a controversial topic where the research results and business practise vary significantly [23] and is, after all, also implicated by many domestic cases.

\section{Evidence from Slovenian Business Practice}

In order to be able to determine the inclusion of strategic partnerships and equity alliances in the strategic directions of companies, 100 of the largest Slovenian companies were studied in regard to total income comparatively in the years of 2010 and 2015 (the list is published every year in several publications, e.g. [24]). Then, out of the 100 largest companies, only production companies were considered (with the exclusion of construction and energetics); there, out of 41 on the list, 26 are either 100-percent or majority-owned by companies abroad or foreign companies have significant control over their operations. The study of 26 companies that were selected this way showed that these companies could ensure even further successful development due to equity alliances as they remained among the largest in the 2010-2015 period, whereas most of them are among the most successful as well.

An important finding for this discussion was that 10 production companies out of 41 (24.4\%) production companies (from the list of the largest companies), managed to prevent a imminently threatening business crisis with a strategic partnership and equity alliances, or managed to gain control over a crisis that had already begun in this way. Therefore, in these 10 cases, entering strategic partnerships and equity alliances directly functioned as crisis prevention and elimination which represents a quarter of the largest Slovenian production companies from the list of the largest companies in 2015. By investigation deeply into the strategies, structures, process and business models of these companies it can be easily found out that strategic partnerships and equity alliance were the basis for their further existence and development avoiding the threat of crisis appearance.

Regardless of the limitations of the research (while equity connections are transparent, the non-equity or contractual strategic partnerships that can take extremely diverse and complex forms, are not, e.g. [25], and represent $60 \%-85 \%$ of all connections [26], it is possible to adopt the initially set hypothesis that strategic partnerships and equity alliances are often functioning within crisis prevention and management (positive correlation), even when the largest companies are concerned.

A further finding was that the studied production companies with equity alliances, in order to ensure continuous development, had to implement a set of revolutionary changes with methods of restructuring or reengineering that were, in the short-term, 
not detected as pleasant in the internal or in the external environment (lay-offs, cancellations of traditional programs and trademarks, divestitures, fundamental change of strategic directions or even visions etc.). This way, the other hypothesis in this contribution was adopted, namely, that allows for an inseparable connection with revolutionary changes between a strategic partnership and equity alliances when they are in the function of crisis prevention and elimination, as positive effects cannot be achieved otherwise.

In light of this research, it is particularly interesting to find that, in the 2003-2008 period, connections also emerged in the field of construction and financial holdings as a fad when it was often that excessive activity of share takeovers and share purchases took place, and also various competitions in the purchases of a certain company and other forms of capital transactions for the realization of non-business or non-economic interests, whereby the development or even urgency of coping with the crisis in one's own company was ignored. The obsession with takeovers had negative consequences that were shown in the exhaustion of the company (the purchase of shares must be supported by appropriate resources), the shifting of focus from one's own problems elsewhere, the redirection of developmental investments (assets are being directed to takeover activities instead of to one's own technology, personnel and markets), and the inappropriate approach to coping with the crisis (instead of implementing fundamental internal measures, the solution to the crisis is searched for in takeovers). The management (and owners) sometimes wish to acquire control over the other, target company at all cost, and therefore opt for complex and dangerous capital adventures, despite the fact that alternative ways of achieving strategic goals would be less risky and cheaper. Such companies are now no longer on the list of the largest companies.

In the studied practice, we often came across the illusionistic reliance of a company's management going through deep crisis believing that the situation they found themselves in would be rectified as soon as they found a "strategic partner", and the matter will simply have to wait until then. As a strategic partner, they envisage someone that will bring them fresh cash to cover all old liabilities due and the development of new projects, ensure the latest technology and provide access to new markets abroad (deus ex machina), and at the same time, will not interfere with the existing management and company operations formed in the past. This is why the management will not settle just with any "strategic partner". However, the harsh reality is different, as the potential acquirer of a company in trouble will turn everything upside-down with radical measures, and in all probability, it will also "thank" the existing management for their services.

\section{Conclusion}

A crisis is a short-term undesired, unfavourable and critical situation in a company (organization), directly endangering the existence and further development of this organization and is caused by an intertwined and simultaneous action of both external and internal sources. Crisis management comprises planning, organizing, directing and monitoring companies experiencing difficulties that directly endanger their existence 
and further development and its purpose is to stop negative trends by achieving a drastic change and providing the foundation for redevelopment. The short-term measures of crisis management that put a stop to negative movements (survival) in the first phase, must be followed in the second phase by middle- or long-term measures of ensuring development that are mostly connected to revolutionary changes, such as the methods of restructuring and reengineering that play a key role also in strategic partnerships and equity alliances. Based on the theoretical discussion and empirical findings from the author's research, two statements that were set forth in advance (hypotheses) were confirmed. Strategic partnerships and equity alliances are often in the function of crisis prevention and management (in the research, 24.4\% of cases among the largest production companies). There is an inseparable connection between strategic partnerships and equity alliances on one side when they are in the function of crisis prevention and elimination, and revolutionary changes on the other, as positive effects cannot be achieved otherwise. Certainly, the findings of this research cannot be valid for every comparable business situation; however, it can show one of possible strategic orientations when further existence and development are endangered. Also, on this basis further deeper researches with different focuses can be applied.

\section{References}

[1] Dubrovski, D. (2004) Peculiarities of Managing a Company in Crisis. Total Quality Management \& Business Excellence, 15, 9-10, 1199-1207. http://dx.doi.org/10.1080/1478336042000255578

[2] Dubrovski, D. (2011) Razsežnosti kriznega managementa. Mednarodna fakulteta za družbene, poslovne študije, Celje.

[3] James, E.H. and Wooten, L.P. (2010) Leading under Pressure. Routledge, New York.

[4] Lalonde, C. (2008) Organiser la réponse a la crise. L'Harmattan, Paris.

[5] Roux-Dufort, Ch. (2003) Géreretdécideren situation de crise. Dunod, Paris.

[6] Achrol, R.S., Scheer, L.K. and Stern, L.W. (1990) Designing Successful Transorganizational Marketing Alliances. Report No. 90-118, Marketing Science Institute, Cambridge.

[7] Bradley, S.P., Hausman, J.A. and Nolan, R.L. (1993) Globalization, Technology and Competition. Harvard Business School Press, Boston.

[8] de la Sierra, M.C. (1995) Managing Global Alliances. Addison-Wesley, Wokingham.

[9] Devlin, G. and Bleackley, M. (1988) Strategic Alliances-Guidelines for Success. Long Range Planning, 21, 18-23. http://dx.doi.org/10.1016/0024-6301(88)90101-X

[10] Faulkner, D. and Johnson, G. (1992) The Challenge of Strategic Management. Cranfield School of Management, London.

[11] Krubasik, E. and Lautenschlager, H. (1993) Forming Successful Strategic Alliances in HighTech Businesses. In: Bleeke, J. and Ernst, D., Eds., Collaborating to Compete, John Wiley \& Sons, New York.

[12] Lewis, J.D. (1990) Partnerships for Profit. The Free Press, New York.

[13] Lynch, R.P. (1993) Business Alliances Guide: The Hidden Competitive Weapon. John Wiley \& Sons, New York.

[14] Spekman, R.E. and Sawhney, K. (1990) Toward a Conceptual Understanding of the Ante- 
cedents of Strategic Alliances. Report No. 90-114, Marketing Science Institute, Cambridge.

[15] Varadarajan, P.R. and Cunningham, M.H. (1995) Strategic Alliances: a Synthesis of Conceptual Foundations. Journal of Academy of Marketing Science, 23, 282-296.

http://dx.doi.org/10.1177/009207039502300408

[16] Berstein, L.A. (1978) Financial Statement Analysis. Irwin, Homewood.

[17] Brouthers, K.D., van Hastenburg, P. and van den Ven, J. (1998) If Most Mergers Fail Why Are They So Popular? Long Range Planning, 31, 347-353.

http://dx.doi.org/10.1016/S0024-6301(98)80002-2

[18] Dubrovski, D. (2009) Management Mistakes as Causes of Corporate Crisis. Total Quality Management \& Business Excellence, 20, 1-2, 39-59. http://dx.doi.org/10.1080/14783360802614281

[19] Meissner, B. (2006) Partnering. VDM Verlag Dr. Müller, Saarbrücken.

[20] Faulhaber, P. and Landwehr, N. (2005) Turnaround-Management in der Praxis. Campus Verlag, Frankfurt.

[21] DePamphilis, D.M. (2008) Mergers, Acquisitions, and Other Restructuring Activities. Elsevier, Burlington.

[22] Sudarsanam, S. (2003) Creating Value from Mergers and Acquisitions. Prentice Hall, Harlow.

[23] Arzac, E.R. (2008) Valuation for Mergers, Buyouts, and Restructuring. John Wiley \& Sons, Hoboken.

[24] Delo (2016) Največja podjetja po prihodkih 2015.

[25] Puslecki, L. (2016) Development of Modes of Cooperation: An Opportunity for Open Innovation Alliances in Polish Biopharmaceutical Industry. Management, 11, 67-80.

[26] Gudergan, S.P., Devinney, T., Richter, N.F. and Ellis, R.S. (2012) Strategic Implications for (Non-Equity) Alliance Performance. Long Range Planning, 45, 451-476.

http://dx.doi.org/10.1016/j.lrp.2012.09.002

\section{Submit or recommend next manuscript to SCIRP and we will provide best service} for you:

Accepting pre-submission inquiries through Email, Facebook, LinkedIn, Twitter, etc.

A wide selection of journals (inclusive of 9 subjects, more than 200 journals)

Providing 24-hour high-quality service

User-friendly online submission system

Fair and swift peer-review system

Efficient typesetting and proofreading procedure

Display of the result of downloads and visits, as well as the number of cited articles

Maximum dissemination of your research work

Submit your manuscript at: http://papersubmission.scirp.org/

Or contact me@scirp.org 